\title{
Relationship of the Significance of Freshwater Use to Health Protocols During the Covid-19 Pandemic in Bantul Village, Yogyakarta
}

\author{
Fahima Ulumia $^{1}$, Moh Syahrul Irfan Fahmi ${ }^{2}$, Relinda Dewi Astabella ${ }^{1}$, Tjahyo Nugroho Adji ${ }^{1}$, Ratih Fitria \\ Putri $^{2 *}$,Heein Yang $^{3}$ \\ ${ }^{1}$ Enviromental Geography, Department of Environmental Geography, Faculty of Geography, Universitas Gadjah Mada, \\ Indonesia \\ ${ }^{2}$ Regional Development, Department of Development Geography, Faculty of Geography, Universitas Gadjah Mada, \\ Indonesia \\ ${ }^{3}$ Departement of Electrical and Computer Engineering, Ajou University, Korea
}

\begin{abstract}
The Covid-19 pandemic has an impact on the use of freshwater. Freshwater has an essential role in preventing the spread of Covid-19 related to the implementation of health protocols also Clean and Healthy Living Behavior. The important factors that influence water use are socioeconomic conditions, including income level, type of work, and education level. The spread of Covid-19 significantly occurs in urban areas. Bantul village is the center of government, economy and one of the planned areas of urban settlements in Bantul Regency. Bantul village is also a hinterland of the Yogyakarta agglomeration area. This study was conducted to determine the influence of socio-economic conditions on the significance of changes in water use during the Covid-19 pandemic to implement health protocols in Bantul village. The data was obtained through interviews with 99 respondents based on random sampling techniques. This research was conducted with quantitative methods and descriptive analysis techniques. The result shows an increase in freshwater use during the pandemic, particularly washing hands and taking a shower. The highest increase in freshwater use is in Kurahan Hamlet. While in Grujugan Hamlet, there has been no increase. The increase in freshwater use indicates the suitable implementation of health protocols.
\end{abstract}

\section{Introduction}

The Covid-19 pandemic has caused profound impacts on human life and the environment, including freshwater use globally [1]. The primary benefit of freshwater for residents is the need for domestic water used daily, such as drinking, cooking, bathing, washing, and cleaning equipment. The use of freshwater for daily activities helps people avoid various diseases. Freshwater supports the sustainability of all lives, especially during the Covid-19 pandemic. During the Covid-19 pandemic, frequent handwashing with soap and water is recommended as one of the most effective measures to reduce the spread of infection. Regular handwashing with soap and running water is a preventive measure of Covid-19 transmission recommended by WHO and the Ministry of Health [2]. The current Covid-19 pandemic has caused the use of freshwater to increase, especially in central areas of activity and high population density.
The amount of domestic water use in each region is different. The amount of water use is influenced by population and type of activity [3]. The high population and activity lead to higher water use. According to the research by [4], domestic water use is influenced by income levels and technology. The urban center of China has more per capita domestic water use than its suburbs, while American urban centers have lower per capita water use than their suburbs. Residents of American urban centers have high incomes and watersaving technology so that the water use per capita of the population is less.

Bantul sub-district is the capital of Bantul Regency. Bantul sub-district consists of 5 villages, namely Palbapang, Ringinharjo, Bantul, Trirenggo, and Sabdodadi. Among the five villages, Bantul Village has the highest population density. Bantul Village is in the center of the Bantul Sub-district and becomes the center of activity in the Bantul Regency. Population density is not the leading cause and has no significant effect on the spread of Covid-19 [5]. However, high population

\footnotetext{
* Corresponding author: ratihfitria.putri@ugm.ac.id
} 
density can lead to faster disease transmission with a more compact and complex spread chain. Bantul Village as a center of activity is also an additional trigger in the spread of Covid-19. Thus, preventing the spread of the Covid-19 virus by carrying out health protocols, especially the use of clean water, is very important. Bantul Village residents have socio-economic characteristics, water needs, and diverse freshwater usage patterns. Based on this description, this study aims to (1) identify the socio-economic characteristics of the population and its effect on the level of water needs; (2) identify the socio-economic characteristics of the population towards the application of health protocols; and (3) analyze the significance of the increased water needs during the pandemic to the application of health protocols.

Research for correlations of the community's socioeconomic conditions on the significance of changes in water use during the Covid-19 pandemic to implement health protocols has never been carried out by other researchers. Previous research was limited to observing the socio-economic influence of the community on water use patterns. The existence of this research can deepen understanding related to water use patterns in the community so that it is known the factors that influence and the extent to which people use it for implementing health protocols.

\section{Methods}

This research is included in the descriptive quantitative type to look for correlations of the community's socioeconomic conditions on the significance of changes in water use during the Covid-19 pandemic to implement health protocols in Bantul Villages. In this case, water use is defined as the daily water requirement in the household for daily activities such as bathing, washing, and watering. Water use is based on the average daily clean water use and the number of family members or by using the following formula [6]:

$$
\text { Domestic water needs: } \frac{[\text { Water Needs/Families/Days }]}{[\text { Number of people per Family }(\text { person })]}
$$

The population used in this study was the Head of Family in Bantul Villages which has 16,535 families [7]. In this case, the number of samples is determined using the Slovin formula This formula allows a researcher to sample the population with a certain level of accuracy [8].

$$
\mathrm{n}=\frac{N}{N(d)^{2}+1}
$$

$\mathrm{N}=$ Population size

$\mathrm{n}=$ Size of sample required

$\mathrm{d}=$ Default error used $(0,1)$

The formula is known as the number of 99 respondents with the level of error used by $10 \%$. This is because the population is known to be quite large. There are limitations in terms of the source of funds, time, and energy available. Then by using the proportional random sampling technique, the distribution of sample proportions in 12 hamlets in Bantul Villages (figure 1).

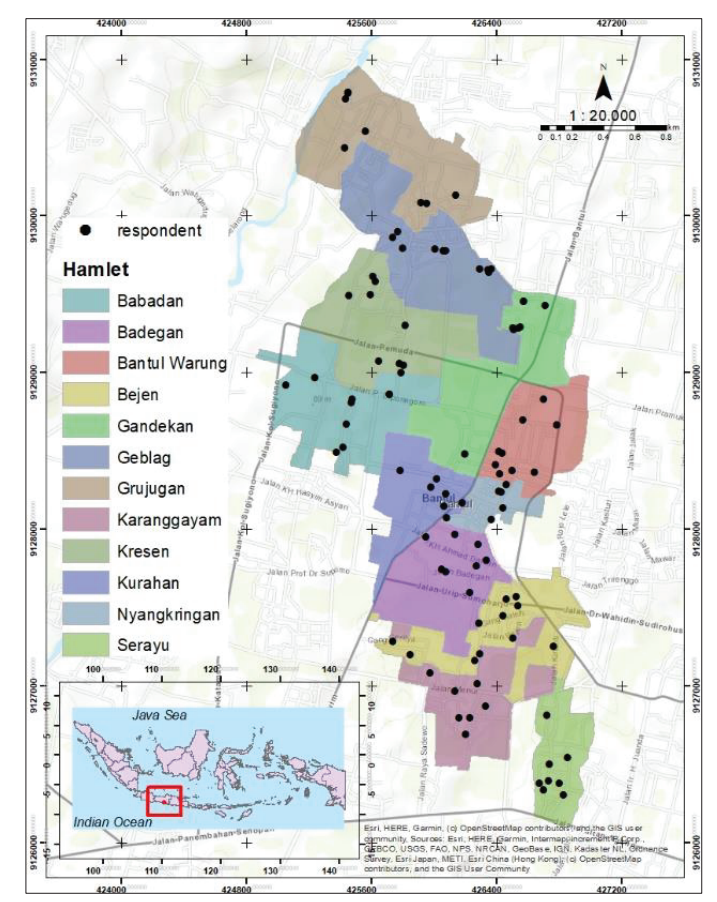

Fig. 1. Distribution of research respondents in Bantul Village

Sampling data is done by sharing questionnaires by creating a list of questions related to the focus of the research. Population water usage data is processed using SPSS (Statistical Package for Social Sciences) application. Analysis of water usage data before and during the Covid-19 Pandemic was conducted with significance tests using the Wilcoxon test. This test is used for normal non-redistributed data characters. Statistical test results are analyzed using descriptive analysis. This is the easiest to interpret and perfectly suited for collating and summarizing quantitative data [9]. However, the analysis was carried out without intending to make conclusions that apply to the public or generalization [10].

\section{Results and Discussions}

\subsection{The Amount of Domestic Water Use}

The average amount of domestic water use per capita in urban areas is 171 liters/day/capita and that in rural area is 114 liters/day/capita [11]. Based on the survey, the amount of domestic water use per capita of Bantul Villages varies greatly, ranging from 54 liters/day to 1044 liters/day. The amount of water use per capita is classified into three classes: low (66-325.5 liters/day/ capita), medium (325.6-651 liters/day/capita), and high (651.1-1,042.5 liters/day/capita). Based on 99 respondents as representatives of the population in Kalurahan Bantul, 91 respondents with moderate per 
capita water use $(91.9 \%)$, one respondent with low per capita water use (1\%), and seven respondents with high per capita water use $(7.1 \%)$. This proves that it is infrequent for the population to have too little or too much water uses than the National Standard that has been set. Based on the analysis results, variations in domestic water use are not influenced by socioeconomic conditions. This is evidenced by the absence of a pattern formed when domestic water use data is crosstab with income levels, types of jobs, and education levels (table 1).

Table 1. Crosstab results (a) the level of education and water use. (b) the type of work and water use. (c) the income level and water use.

\begin{tabular}{|l|c|c|c|c|}
\hline $\begin{array}{r}\text { Classification } \\
\text { of normal } \\
\text { water use }\end{array}$ & High & Medium & Low & Total \\
\hline No education & 1 & 0 & 5 & 6 \\
\hline Primary School & 1 & 0 & 10 & 11 \\
\hline Junior High School & 2 & 0 & 7 & 9 \\
\hline High School & 2 & 1 & 47 & 50 \\
\hline Bachelor & 0 & 0 & 1 & 1 \\
\hline Master & 7 & 1 & 91 & 99 \\
\hline Total & 1 & 0 & 5 & 6 \\
\hline
\end{tabular}

(a)

\begin{tabular}{|l|c|c|c|c|}
\hline $\begin{array}{r}\text { Classification } \\
\text { of normal } \\
\text { water use }\end{array}$ & High & Medium & Low & Total \\
\hline Profession & 0 & 0 & 2 & 2 \\
\hline Unemployment & 0 & 0 & 1 & 1 \\
\hline Breeder & 0 & 0 & 3 & 3 \\
\hline Entlege student & 0 & 0 & 3 & 3 \\
\hline Farmereneur & 1 & 0 & 10 & 11 \\
\hline Government employees & 0 & 0 & 5 & 5 \\
\hline Housewife & 1 & 1 & 27 & 29 \\
\hline Laborer & 1 & 0 & 3 & 4 \\
\hline Private & 2 & 0 & 17 & 19 \\
\hline Retired & 2 & 0 & 9 & 11 \\
\hline Teacher & 0 & 0 & 3 & 3 \\
\hline Trader & 0 & 0 & 8 & 8 \\
\hline Total & 7 & 1 & 91 & 99 \\
\hline
\end{tabular}

(b)

\begin{tabular}{|l|c|c|c|c|}
\hline $\begin{array}{r}\text { Classification } \\
\text { of normal } \\
\text { water use } \\
\text { Income }\end{array}$ & High & Medium & Low & Total \\
\hline Low $(<1500000)$ & 3 & 0 & 25 & 28 \\
\hline Medium $(1500000-2500000)$ & 2 & 0 & 19 & 21 \\
\hline High $(2500000-3500000)$ & 2 & 1 & 10 & 13 \\
\hline Very high $(>3500000)$ & 0 & 0 & 37 & 37 \\
\hline Total & 7 & 1 & 91 & 99 \\
\hline
\end{tabular}

(c)

Source: Data processing, 2021

\subsection{Pandemic and Significance of Water Use}

Pandemics have a substantial impact on water use in areas with larger populations. Overall, the effect is in the form of increased domestic water use in urban areas. The results follow the study by [12], which stated an increase in water use in the settlement category. The increase in the use of clean water in Bantul Village for bathing needs occurred by $4.6 \%$, while the increase in the use of clean water for hand washing purposes occurred very significantly by $101.4 \%$. This figure increased dramatically compared to the pre-pandemic situation of Covid-19. Table 2 describes in more detail the increasing use of clean water for various domestic needs from pre-pandemic conditions and during pandemics.

Considering the variation of average water consumption before and during the pandemic, there was an increase in water use of 13.5 liters/day/capita. Figure 2 shows a map showing the distribution of the significance of total water consumption, both for bathing and handwashing in each Hamlets. The consumption of clean water began to increase even before the quarantine period began. Nevertheless, all categories appear to be affected by measures to limit the spread of pandemics, especially the implementation of health protocols and clean and healthy living behaviors.

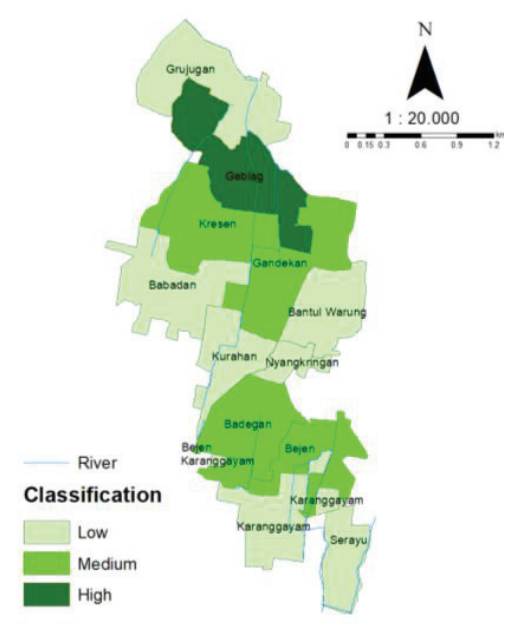

(a)

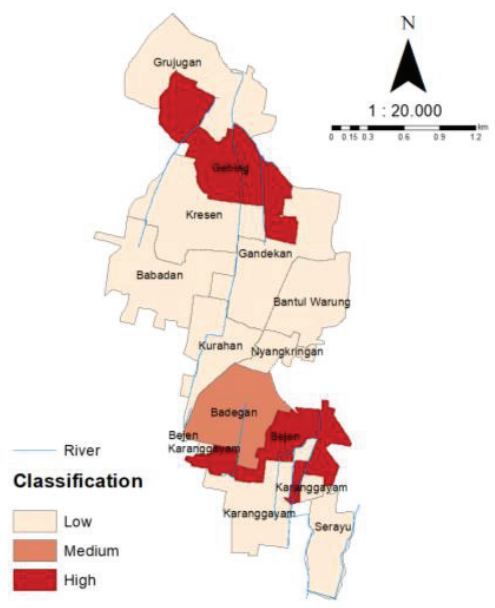

(b)

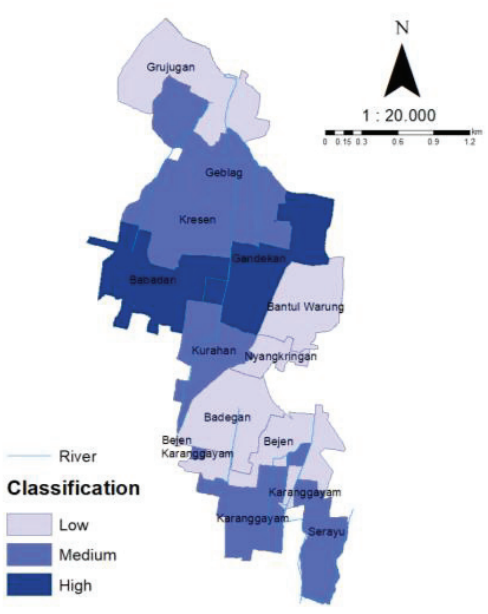

(c)

Fig. 2. Distribution of significance of clean water use during the Covid-19 pandemic. (a) The total significance of water use. (b) Significance of water used for bathing purposes. (c) The significance of the use of water for handwashing.

Source: Data processing, 2021 
Table 2. Significance of Clean Water Use During the Covid-19 Pandemic

\begin{tabular}{|l|c|c|c|c|}
\hline Freshwater Uses & $\begin{array}{c}\text { Before the Covid- } \\
\text { 19 pandemic } \\
\text { (liter/day/capita) }\end{array}$ & $\begin{array}{c}\text { During the Covid-19 } \\
\text { pandemic } \\
\text { (liter/day/capita) }\end{array}$ & $\begin{array}{c}\text { Increase in freshwater } \\
\text { use during the } \\
\text { pandemic } \\
\text { (liter/capita/day) }\end{array}$ & $\begin{array}{c}\text { The signification } \\
\text { of freshwater } \\
\text { use during the } \\
\text { pandemic (\%) }\end{array}$ \\
\hline Take a shower & 178.48 & 186.71 & 8.22 & 4.60 \\
\hline Wash clothes & 31.52 & 31.61 & 0.09 & 0.70 \\
\hline Drinking water & 1.86 & 1.86 & 0.00 & 0.00 \\
\hline Watering plants & 7.08 & 7.08 & 0.00 & 0.00 \\
\hline Cook & 5.24 & 5.34 & 0.10 & 0.75 \\
\hline Wudu' & 10.70 & 10.79 & 0.09 & 0.65 \\
\hline Washing vehicles & 0.89 & 0.89 & 0.00 & 0.00 \\
\hline Hand washing & 4.89 & 9.85 & 4.96 & 101.4 \\
\hline Other & 0.42 & 0.45 & 0.03 & 0.22 \\
\hline
\end{tabular}

Source: Data processing, 2021

Figure $2 \mathrm{a}$ shows the total significance of highcategory clean water use occurring in Geblag Hamlet, while in the category of significance is occurring in Kresen, Gandekan, Badegan, and Bejen Hamlets. The remaining seven hamlets have a low significance category for water use during the Covid-19 pandemic. The significance of the use of clean water is inseparable from the application of health protocols by the people of Bantul Village, one of which is hand washing. During the Covid-19 pandemic, frequent handwashing with soap and water is recommended as one of the most effective measures to reduce the spread of infection. Figure 2c shows almost all communities in each of the Hamlets in Bantul Village experiencing the significance of using water for handwashing.

\subsection{Implementation of Health Protocols}

The increase in clean water using during the pandemic is caused by several factors, including the use of water for bathing and hand washing which is included in the application of health protocols. The amount of water reportedly used for handwashing that has allowed reduction of fecal contamination ranges from 0.5-2 liters per person. In addition, WHO and UNICEF also recommend washing hands in running water with soap and rubbing for at least 20 seconds [2]. Water use is significant for handwashing per capita during the Covid-19 and pre-Covid-19 pandemics of 4.9 liters and 9.9 liters (figure 3), respectively.

The study found that, based on 99 respondents, there are $98.9 \%$ had implemented health protocols, while $1.1 \%$ did not implement health protocols during the Covid-19 pandemic (figure 4). This indicates that people in some districts in Bantul Village have implemented suitable health protocols following the government's recommendations. The increase in the use of water for handwashing during Covid-19 is also coherent with other studies.
According to research by [13], people begin to wash their hands during activities outside routinely and after returning from outside during the pandemic situation.

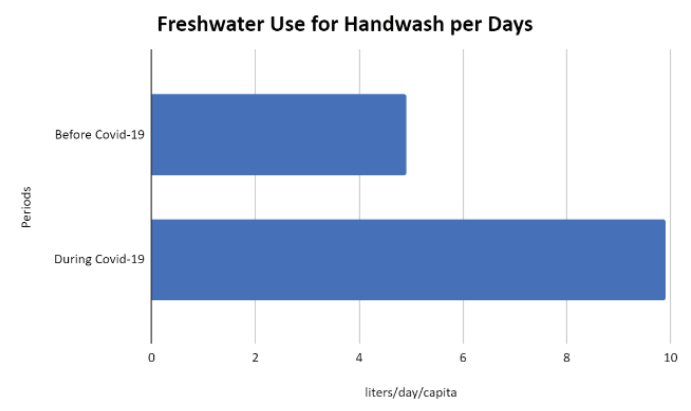

Fig. 3. Use of clean water for hand washing purposes per day during the Covid-19 and pre-Covid-19 pandemics.

Source: Data processing, 2021

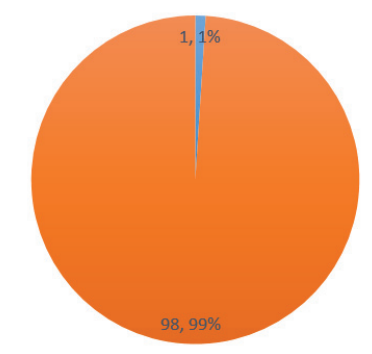

- percentage of people not implementing health protocols (\%)

- percentage of people implementing health protocols (\%)

Fig. 4. Percentage of health protocol and implementation in Bantul Village.

Source: Data processing, 2021 


\subsection{Socio-economic and Significance of Water Use}

The significance of Bantul Villages domestic water use is mostly at low levels. The survey results showed that out of a total of 99 respondents, 96 respondents had the significance of domestic water use at a low level (0-77.2 liters/day/capita), while two respondents at the moderate level (77.3-154.4 liters/day/capita) and one respondent at the high level (154.5-231.7 liters/day/capita).

Table 3. shows crosstab results between education level, income level, and type of work with the significance of water use. Crosstab results showed no pattern between socio-economic characteristics and the significance of household water use. Low or high levels of education, employment, and incomes have low domestic water use significance. This indicates that socio-economic characteristics do not affect the significance of water use.

Table 3. Crosstab results (a) the level of education and significance of water use. (b) the income level and significance of water use. (c) the type of work and significance of water use.

\begin{tabular}{|l|c|c|c|c|}
\hline $\begin{array}{r}\text { Classification } \\
\text { of water use } \\
\text { significance }\end{array}$ & High & Medium & Low & Total \\
\hline No education & 0 & 0 & 6 & 6 \\
\hline Primary School & 0 & 0 & 11 & 11 \\
\hline Junior High School & 0 & 0 & 9 & 9 \\
\hline High School & 1 & 0 & 49 & 50 \\
\hline Bachelor & 0 & 2 & 20 & 22 \\
\hline Master & 0 & 0 & 1 & 1 \\
\hline Total & 1 & 2 & 96 & 99 \\
\hline
\end{tabular}

(a)

\begin{tabular}{|l|c|c|c|c|}
\hline $\begin{array}{c}\text { Classification } \\
\text { of water use } \\
\text { significance }\end{array}$ & High & Medium & Low & Total \\
\hline Profession & 0 & 0 & 2 & 2 \\
\hline Bnemployment & 0 & 0 & 1 & 1 \\
\hline College student & 0 & 0 & 3 & 3 \\
\hline Entrepreneur & 0 & 0 & 3 & 3 \\
\hline Farmer & 0 & 0 & 11 & 11 \\
\hline Government employees & 0 & 0 & 5 & 5 \\
\hline Housewife & 0 & 0 & 29 & 29 \\
\hline Laborer & 0 & 0 & 4 & 4 \\
\hline Private & 0 & 0 & 19 & 19 \\
\hline Retired & 0 & 1 & 10 & 11 \\
\hline Teacher & 1 & 1 & 1 & 3 \\
\hline Trader & 0 & 0 & 8 & 8 \\
\hline Total & 1 & 96 & 2 & 99 \\
\hline
\end{tabular}

(b)

\begin{tabular}{|l|c|c|c|c|}
\hline $\begin{array}{c}\text { Classification } \\
\text { of water use } \\
\text { significance }\end{array}$ & High & Medium & Low & Total \\
Income & & & \\
\hline Lowsification $(<1500000)$ & 0 & 0 & 28 & 28 \\
\hline Medium $(1500000-2500000)$ & 0 & 0 & 21 & 21 \\
\hline High $(2500000-3500000)$ & 0 & 0 & 13 & 13 \\
\hline Very high $(>3500000)$ & 1 & 2 & 34 & 37 \\
\hline Total & 1 & 2 & 96 & 99 \\
\hline
\end{tabular}

(c)

Source: Data processing, 2021

\subsection{Socio-economic and Health Protocols}

The socio-economic characteristics of Bantul villagers are classified based on the level of education, the level of income, and the type of work. Tables 4,5 , and 6 show crosstab results between education level, income level, and job type with the type of implementation of health protocol. Although, in general, all respondents apply hand washing or handwashing and bathing as a health protocol that is often applied. It can be seen the type of health protocol based on the most dominant respondents.

Table 4. Crosstab results between the income level and the implementation of health protocols.

\begin{tabular}{|l|c|c|c|c|c|}
\hline $\begin{array}{l}\text { Income } \\
\text { Implassification } \\
\text { of health protocols }\end{array}$ & I1 & I2 & I3 & I4 & Total \\
\hline Hand washing & 12 & 3 & 1 & 12 & 28 \\
\hline Hand washing, hand sanitizer & 0 & 0 & 0 & 2 & 2 \\
\hline Hand washing, mask & 1 & 1 & 2 & 1 & 5 \\
\hline $\begin{array}{l}\text { Hand washing, mask, hand } \\
\text { sanitizer }\end{array}$ & 0 & 0 & 0 & 1 & 1 \\
\hline $\begin{array}{l}\text { Hand washing, mask, physical } \\
\text { distancing }\end{array}$ & 0 & 1 & 1 & 1 & 3 \\
\hline $\begin{array}{l}\text { Hand washing, physical } \\
\text { distancing }\end{array}$ & 1 & 0 & 0 & 0 & 1 \\
\hline Hand washing, take a shower & 10 & 12 & 8 & 6 & 36 \\
\hline $\begin{array}{l}\text { Hand washing, take a shower, } \\
\text { disinfectant }\end{array}$ & 0 & 0 & 0 & 1 & 1 \\
\hline $\begin{array}{l}\text { Hand washing, take a shower, } \\
\text { mask }\end{array}$ & 2 & 3 & 1 & 10 & 16 \\
\hline $\begin{array}{l}\text { Hand washing, take a shower, } \\
\text { mask, hand sanitizer }\end{array}$ & 0 & 0 & 0 & 2 & 2 \\
\hline $\begin{array}{l}\text { Hand washing, take a shower, } \\
\text { mask, physical distancing }\end{array}$ & 1 & 1 & 0 & 0 & 2 \\
\hline Hand sanitizer & 0 & 0 & 0 & 1 & 1 \\
\hline Not implement & 1 & 0 & 0 & 0 & 1 \\
\hline Total & 28 & 21 & 13 & 37 & 99 \\
\hline
\end{tabular}

I1. Low $(<\mathrm{Rp} \mathrm{1.500.000);} \mathrm{I2.} \mathrm{Medium} \mathrm{(Rp} \mathrm{1.500.000-Rp}$ 2.500.000); I3. High (Rp 2.500.000- Rp 3.500.000); I4. Very High $(>\operatorname{Rp} 3.500 .000)$

Source: Data processing, 2021

Table 4 shows the crosstab results between income levels and the implementation of health protocols. Most of the respondents have a highincome level ( $>$ Rp 3,500,000). However, most respondents applied slightly more handwashing than other health protocols. In addition to hand washing and bathing, respondents have been able to apply health protocols in the form of the use of masks. It is seen in every crosstab result that the application of health protocols in the form of hand washing, bathing, and wearing masks has often been applied by respondents in all socio-economic characteristics. 
Table 5. Crosstab results between the type of work and the implementation of health protocols.

\begin{tabular}{|c|c|c|c|c|c|c|c|c|c|c|c|c|c|}
\hline $\begin{array}{l}\text { Implementation of health } \\
\text { protocols }\end{array}$ & P1 & P2 & P3 & P4 & P5 & P6 & P7 & P8 & P9 & P10 & P11 & P12 & Total \\
\hline Hand washing & 2 & 1 & 1 & 1 & 3 & 1 & 7 & 1 & 4 & 2 & 1 & 4 & 28 \\
\hline Hand washing, hand sanitizer & 0 & 0 & 0 & 0 & 0 & 0 & 0 & 0 & 0 & 2 & 0 & 0 & 2 \\
\hline Hand washing, mask & 0 & 0 & 0 & 0 & 0 & 0 & 3 & 1 & 0 & 1 & 0 & 0 & 5 \\
\hline Hand washing, mask, hand sanitizer & 0 & 0 & 0 & 0 & 0 & 0 & 0 & 0 & 0 & 1 & 0 & 0 & 1 \\
\hline Hand washing, mask, physical distancing & 0 & 0 & 0 & 1 & 0 & 0 & 1 & 0 & 0 & 1 & 0 & 0 & 3 \\
\hline Hand washing, physical distancing & 0 & 0 & 0 & 0 & 1 & 0 & 0 & 0 & 0 & 0 & 0 & 0 & 1 \\
\hline Hand washing, take a shower & 0 & 0 & 2 & 1 & 5 & 2 & 12 & 2 & 7 & 3 & 0 & 2 & 36 \\
\hline Hand washing, take a shower, disinfectant & 0 & 0 & 0 & 0 & 0 & 1 & 0 & 0 & 0 & 0 & 0 & 0 & 1 \\
\hline Hand washing, take a shower, mask & 0 & 0 & 0 & 0 & 2 & 1 & 4 & 0 & 6 & 0 & 2 & 1 & 16 \\
\hline Hand washing, take a shower, mask, hand sanitizer & 0 & 0 & 0 & 0 & 0 & 1 & 0 & 0 & 0 & 1 & 0 & 0 & 2 \\
\hline $\begin{array}{l}\text { Hand washing, take a shower, mask, physical } \\
\text { distancing }\end{array}$ & 0 & 0 & 0 & 0 & 0 & 0 & 1 & 0 & 0 & 0 & 0 & 1 & 2 \\
\hline Hand sanitizer & 0 & 0 & 0 & 0 & 0 & 1 & 0 & 0 & 0 & 0 & 0 & 0 & 1 \\
\hline Not implement & 0 & 0 & 0 & 0 & 0 & 0 & 1 & 0 & 0 & 0 & 0 & 0 & 1 \\
\hline Total & 2 & 1 & 3 & 3 & 11 & 7 & 29 & 4 & 17 & 11 & 3 & 8 & 99 \\
\hline
\end{tabular}

P1. Unemployment; P2. Breeder; P3. College Student; P4. Entrepreneur; P5. Farmer; P6. Government employee; P7. A housewife; P8. Laborer; P9. Private; P10. Retired; P11. Teacher; P123. Trader.

Source: Data processing, 2021

Table 6. Crosstab results between the level of education and the implementation of health protocols.

\begin{tabular}{|c|c|c|c|c|c|c|c|}
\hline $\begin{array}{l}\text { Education } \\
\text { Implementation } \\
\text { of health } \\
\text { protocols }\end{array}$ & E1 & E2 & E3 & E4 & E5 & E6 & Total \\
\hline Hand washing & 0 & 2 & 2 & 18 & 6 & 0 & 28 \\
\hline $\begin{array}{l}\text { Hand washing, } \\
\text { hand sanitizer }\end{array}$ & 0 & 0 & 0 & 1 & 1 & 0 & 2 \\
\hline $\begin{array}{l}\text { Hand washing, } \\
\text { mask }\end{array}$ & 0 & 1 & 0 & 3 & 1 & 0 & 5 \\
\hline $\begin{array}{l}\text { Hand washing, } \\
\text { mask, hand } \\
\text { sanitizer }\end{array}$ & 0 & 0 & 0 & 0 & 1 & 0 & 1 \\
\hline $\begin{array}{l}\text { Hand washing, } \\
\text { mask, physical } \\
\text { distancing }\end{array}$ & 0 & 0 & 0 & 1 & 2 & 0 & 3 \\
\hline $\begin{array}{l}\text { Hand washing, } \\
\text { physical } \\
\text { distancing }\end{array}$ & 0 & 0 & 0 & 1 & 0 & 0 & 1 \\
\hline $\begin{array}{l}\text { Hand washing, } \\
\text { take a shower }\end{array}$ & 4 & 6 & 4 & 18 & 4 & 0 & 36 \\
\hline $\begin{array}{l}\text { Hand washing, } \\
\text { take a shower, } \\
\text { disinfectant }\end{array}$ & 0 & 0 & 0 & 0 & 0 & 1 & 1 \\
\hline $\begin{array}{l}\text { Hand washing, } \\
\text { take a shower, } \\
\text { mask }\end{array}$ & 1 & 1 & 3 & 6 & 5 & 0 & 16 \\
\hline $\begin{array}{l}\text { Hand washing, } \\
\text { take a shower, } \\
\text { mask, hand } \\
\text { sanitizer }\end{array}$ & 0 & 0 & 0 & 1 & 1 & 0 & 2 \\
\hline $\begin{array}{l}\text { Hand washing, } \\
\text { take a shower, } \\
\text { mask, physical } \\
\text { distancing }\end{array}$ & 1 & 0 & 0 & 1 & 0 & 0 & 2 \\
\hline Hand sanitizer & 0 & 0 & 0 & 0 & 1 & 0 & 1 \\
\hline Not implement & 0 & 1 & 0 & 0 & 0 & 0 & 1 \\
\hline Total & 6 & 11 & 9 & 50 & 22 & 1 & 99 \\
\hline
\end{tabular}

E1. No education; E2. Primary School; E3. Junior High School; E4. High School; E5. Bachelor E6. Master

Source: Data processing, 2021
Table 5 shows the crosstab results between job types and the implementation of health protocols. Of the 99 participants, 29 were housewives. Most housewives apply more hand washing and bathing. Table 6 shows the crosstab results between education levels and health protocols. Of the 99 participants, 50 respondents have the last level of high school education. Most respondents applied hand washing and hand washing and bathing with the same proportion.

The crosstab results do not show any pattern between socio-economic characteristics and health protocols applied by the residents of Bantul Village. This indicates that socio-economic characteristics do not affect the type of health protocols applied by Bantul Village residents. Finally, the type of health protocol carried out by the residents of Bantul Village generally is not influenced by socioeconomic characteristics. All respondents with different socio-economic characteristics (education level, income level, and type of occupation) applied handwashing or handwashing and bathing as a form of frequently applied health protocol measures.

\section{Conclusion}

The Covid-19 pandemic had an impact on freshwater use in larger areas. Overall, the real impact is the increasing use of freshwater in the domestic sector by residents in urban areas. Bantul Village residents have socio-economic characteristics, water needs, and diverse clean water usage patterns. Low and high levels of education, employment, and income have low household water use significance. This indicates that socio-economic characteristics do not affect the significance of water use. The amount of household freshwater use per 
capita of Bantul Village is very high, ranging from 54 liters/day to 1,044 liters/day. In addition, socioeconomic characteristics do not affect the type of health protocols applied by Bantul Village residents. However, the variations of the average water consumption before and during the pandemic occurred, there was a water usage significance of 13.5 liters/day/capita.

The significance of the use of freshwater during the pandemic is most for bathing and washing hands. The increase of freshwater use is very high in Kurahan Hamlet, while in Grujugan Hamlet, there is no increase. The increase in freshwater use indicates the suitable implementation of health protocols. Based on 99 respondents, there are $98.9 \%$ had implemented health protocols, while $1.1 \%$ did not implement health protocols during the Covid-19 pandemic. So further studies are required not only in Bantul Village but also worldwide. New findings of this study will benefit future research to comprehensively assess the socio-economic impact associated with the significance of freshwater use in developed and developing countries due to new health protocols also clean and healthy living behavior during the Covid-19 outbreak.

\section{References}

1. R. Pant, K.Bishwakarma, R. F. U. Qaiser, L. Pathak, G. Jayaswal, B. Sapkota, K. B. Pal, L. B. Thapa, Koirala, M., Rijal, K., R. Maskey, J. Environ. Manage, 289 (2021)

2. WHO and UNICEF, Water, sanitation, hygiene, and waste management for the COVID-19 virus [website], (2020)

(https://apps.who.int/iris/bitstream/handle/10 665/331846/WHO-2019-nCoV-IPC_WASH2020.3-eng.pdf?ua=1, accessed 9 June 2021)

3. World Health Organization, Water Sanitation and Health [website], (2020)

(https://www.who.int/teams/environmentclimate-change-and-health/water-sanitationand-health/environmental-health-inemergencies/humanitarian-emergencies, accessed 9 June 2021)

4. Y. Z. Wang, Y. Franz, K. Zhang, X. Ding, K. Jia, G. Yuan., Resour. Conserv. Recycl., 169 (2021)

5. D. Wahyuni, J. Geo. Edu. dan Ling., 5, 1 (2021)

6. P. N. Cahyo, P. Hadi, T. N. Adji, Maj. Geogr. Indones., 30, 2 (2016)

7. Badan Pusat Statistik, Bantul Subdistrict in Figures, in Katalog BPS (2020)

8. E. Stephanie, Slovin's Formula Sampling Techniques (Houghton-Mifflin, New York, 2003).

9. G. Marshall, L. Jonker, The College of Radiography, 16 (2010)
10. Sugiyono. Metode Penelitian Kuantitatif, Kualitatif, dan R\&D, (Alfabeta, Bandung, 2017)

11. Asian Development Bank, Indonesia: Country Water Assessment (2016)

12. K. Andreza, E. Henning, M. P. Brikalski, F. V. de Luca, A. C. Konrath, Resour. Conserv. Recycl., 163 (2020)

13. A. Sayeed, M. H. Rahman, J. Bundschuh, I. Herath, F. Ahmed, P. Bhattacharya, Groundw. Sustain. Dev., 13 (2021) 